\title{
Regionalization of the Climatic Areas of Qazvin Province Using Multivariate Statistical Methods
}

\author{
Fatemeh Shahriar $^{1}$, Majid Montazeri ${ }^{2}$, Mehdi Momeni $^{1} \&$ Alireza Freidooni ${ }^{3}$ \\ ${ }^{1}$ Faculty of Humanities, Najafabad Branch, Islamic Azad University, Najafabad, Isfahan, Iran \\ ${ }^{2}$ Assistant Professor of Climatology, University of Isfahan, Isfahan, Iran \\ ${ }^{3}$ Faculty of Management and Accounting, Qazvin Branch, Islamic Azad University, Qazvin, Iran \\ Correspondence: Fatemeh Shahriar, Faculty of Humanities, Najafabad Branch, Islamic Azad University, \\ Najafabad, Isfahan, Iran. E-mail: af_shahryar@yahoo.com
}

Received: September 21, 2014 Accepted: October 8, 2014 Online Published: January 10, 2015

doi:10.5539/mas.v9n2p123 URL: http://dx.doi.org/10.5539/mas.v9n2p123

\begin{abstract}
The logical explanation about the spatial organization and usage of local capabilities and application of basic strategic to obviate complications is required to identifying the environment and using modern techniques to achieve this goal. Climatic regionalization or knowing different climatic regions is necessary for planning and territory sustainable development. The aim of this research is to recognize the most influential climatic elements affecting the climate of Qazvin province, and the spatial separation of climatic regions by using multivariate statistical methods. To this end, mean data of 28 climatic elements in 20 internal synoptic climatology stations both inside and adjacent to the borders of Qazvin Province were gathered and exploited. The correlated matrices of standardized data of the 28 climatic elements were analyzed using factor analysis in 623 spatial pixels, in the province of Qazvin. This analysis on the correlated matrices of standardized data showed that with 9 principal components, more than $99.21 \%$ of the spatial changes of the regional elements in the province can be described. At the same time, the temperature elements, humidity elements and rainfalls have in the central and eastern and north and south evident in the province. Applying agglomerative hierarchical cluster analysis in "ward" method by the combination style applied on the scores of the 9 principal components showed that the province can be classified into 9 climatic regions. This classification is matched a lot with the environmental realities of the province, especially the mountains configuration.
\end{abstract}

Keywords: Qazvin province, climatic regionalization, kriging interpolation, factor analysis, cluster analysis

\section{Introduction}

One of the most elemental factors in the structure of the planet earth is climates. Climatic conditions affect very extensively human beings and all sorts of life. As such, the climate of every territory is a very important factor in the study of the activities performed by human beings. The goal of this science is to discover and explain the natural behavior of the atmosphere and benefit from it in line with the interests of human beings (Mohammadi, 2010). To achieve this goal, it is necessary to synthesize the climatic data and elements by different statistical methods in order to identify the climates and present them within a regular and systematic framework with the totality of the location and in a long term so that they are usable in forecasts and different plans.

One of the statistical methods of analyzing the existing information within the datasets is the factor analysis method which is used to determine the most effective variables when the number of the variables under study are numerous and relations between them is unknown. The most important aim of using factor analysis is to reduce the size of the data and determine pinpoint the most important variables in the formation of phenomena.

Benefiting from statistical methods for the classification of climates was first introduced by Steiner in 1965in the US. He performed 16 climatic variables related to 167 meteorology stations using the factor analysis method and divided the US into ten climatic areas (Alijani \& Kaviani, 1992). Aiowad (1978) divided Nigeria climatologically. Guster (1986) identified 3 main and 4 climatic areas by analyzing the main constituents on average temperature of European Mediterranean countries. Erendofer (1987) divided Austria climatologically. White and Perry (1979) divided England and Wales climatologically using the agro-climatic data by main constituents and cluster method. White et al (1991) performed a comparative analysis on rainfall data in 
Pennsylvania. Demraus et al (1993) zoned the Sri Lanka rainfalls using daily data at 42 meteorology stations during 1971-1985. Ahmad and Yousef (1997) using cluster multivariate analysis using 14 climatic variables in 57 meteorological stations in Saudi Arabia divided the country into 9 climatic areas by cluster analysis method. Litman (2000) classified the geo-potential level of 500 Hectopascal using the cluster analysis and reviewed the resultant synoptic equation through rainfalls in the Mediterranean zone.

Gayati et al (2006) used the cluster analysis method in order to zone Greece in terms of solar energy receipt for the construction of schools in the country. Karbajal et al (2007) demonstrated the capabilities of factor analysis by zoning and regionalizing the bioclimatic regions in central and eastern Mexico. Christian (2008) created 6 clusters for the factor and cluster analysis for the purpose of the classification of the data gathered in 56 years. Miao and Dang (2009) divided the region in terms of precipitations in the freezing period and non-freezing period through the 20 degrees index, annual frost, precipitation during the frost period and divided the region into 10 main regions and 24 sub-regions. Hiss et al (2010) zoned the vicinities of the Ling Ding Yang Pear Bay in southern China. Yunus (2011) used factor and cluster analysis for the climatic classification of the Malaysian Peninsula.

In Iran, during the past decades, significant efforts have been made towards the exploitation of the multivariate statistical analysis for the zoning of climatic areas. Masoudian (2004) indicated that in Iran showed that 6 factors play essential roles in the Iranian climate and divided Iran into 15 climatic regions. Ghayour and Montazeri (2004) regionalized the Iranian climatic regimes using the main component analysis and showed that $99 \%$ of data variances can be explained by three constituents. In a research using the cluster analysis on precipitation data, Masoudian (2005) identified three precipitation regimes of winter, and winter-spring and Autumnal in Iran. Masoudian and Kaviani (2009) divided Iran into 8 macro-climatic regions using hierarchical cluster analysis on precipitation data. Montazeri divided Isfahan Province into 10 climatic zones performing analyses on main constituents on 29 climatic elements. Amirahmadi and Abbasnia (2010) pinpointed 4 climatic regions in Esfahan Province by performing analysis on 25 climatic variables. Ghayour and Masoudian (2011) performed chronological and regional analyses on precipitation events using principal constituents analysis (PCA) and cluster analysis (CA) on data gathered at 45 coastal stations of Caspian sea and divided Caspian Coastal Regions (inside Iran ) into 6 homogenous areas.

Since little research has been performed in Qazvin Province using multivariate methods, this paper seeks to pinpoint the climatic equivalent regions, identify the distinguished elements that form the regions climatic figure enabling the identification and representation of the climatic capabilities of the province and pave the way for making the most of the provincial climatic capabilities for environmental planning to be developed in this important Iranian agro-industrial and transportation hub.

\section{Region under Study}

About 15.568 square kilometers in area, Qazvin Province accounts for 1 percent of the area of Iran. It is located in the northern half of Iran. It is located between $35^{\circ} 37^{\prime}$ and $36^{\circ} 45^{\prime}$ northern latitudes and $48^{\circ} 45^{\prime}$ and $50^{\circ} 50^{\prime}$ eastern longitudes (see Figure 1). Although it is not a vast province $\left(26^{\text {th }}\right.$ largest province of Iran), but enjoys a diverse climate because of its location between the dry central plateau and north eastern mountainous regions. It is also widely diverse in terms of altitude (see Figure 2). With 4175 meter mount-Siyalan as the highest point and 300 meter Manjil Dam Lake banks as the lowest point, this difference affects precipitation and temperature in this province, so much so that its annual precipitation ranges from $210 \mathrm{~mm}$ per year in the eastern parts to 550 $\mathrm{mm}$ in the north western parts of the province and the temperature fluctuates widely between the record highs (central plains) and record lows (in the north western Avaj heights). The mean temperature gradually declines from the plane towards the mountain skirts and mountainous regions (Shormij et al, 2012).

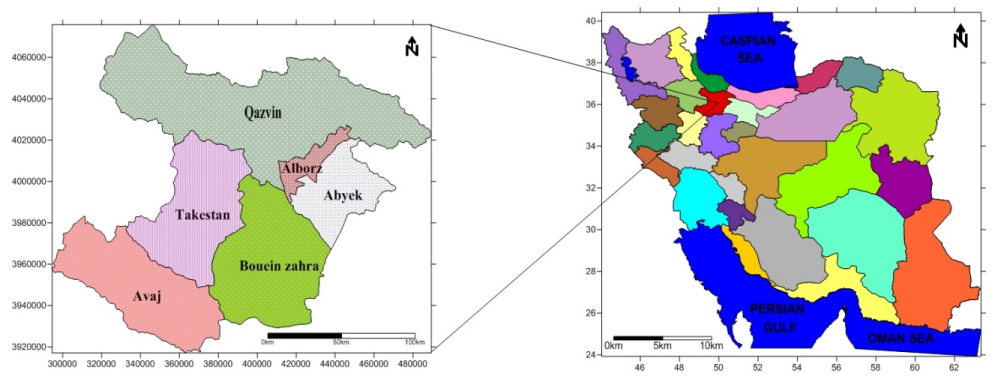

Figure 1. Geographical location of Qazvin Province 


\section{Data and Methodology}

In this study, at first a base comprising 28 synoptic climatologic stations were set up. Data extracted from the Iranian meteorological organization (See Figure 3). Reviews indicated that among the stations built within the province only 2 synoptic stations of Qazvin and Bagh Kowsar have records of their 20 years statistics. Therefore adjacent synoptic stations were also employed. This increased both the exactitude of factor separation and climatic zones and highlighted the role played by the adjacent areas in the climate of the province. The specifications of all stations are shown in Table 1 .

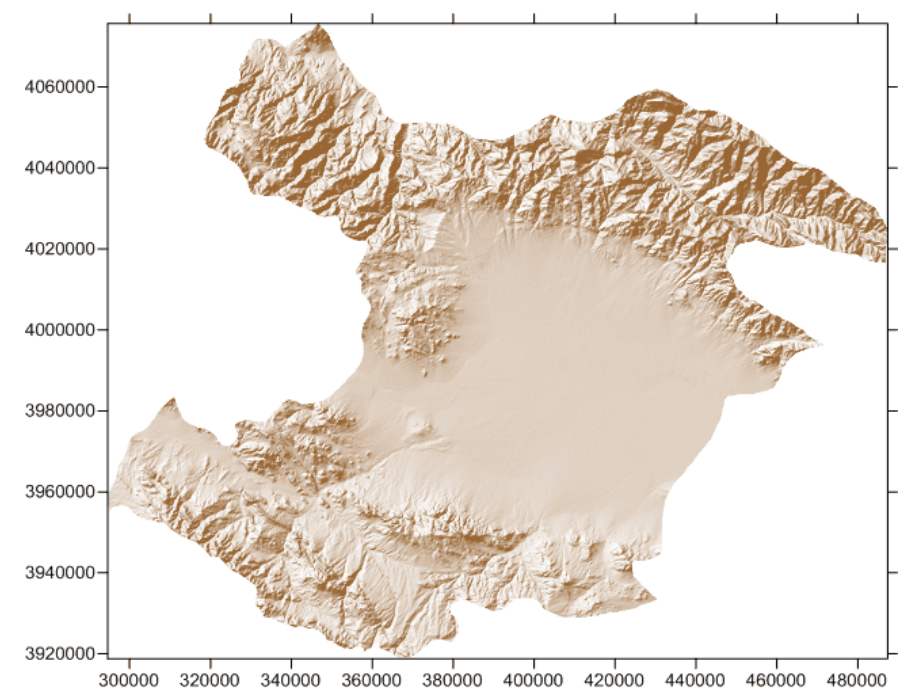

Figure 2. Topology of Qazvin Province

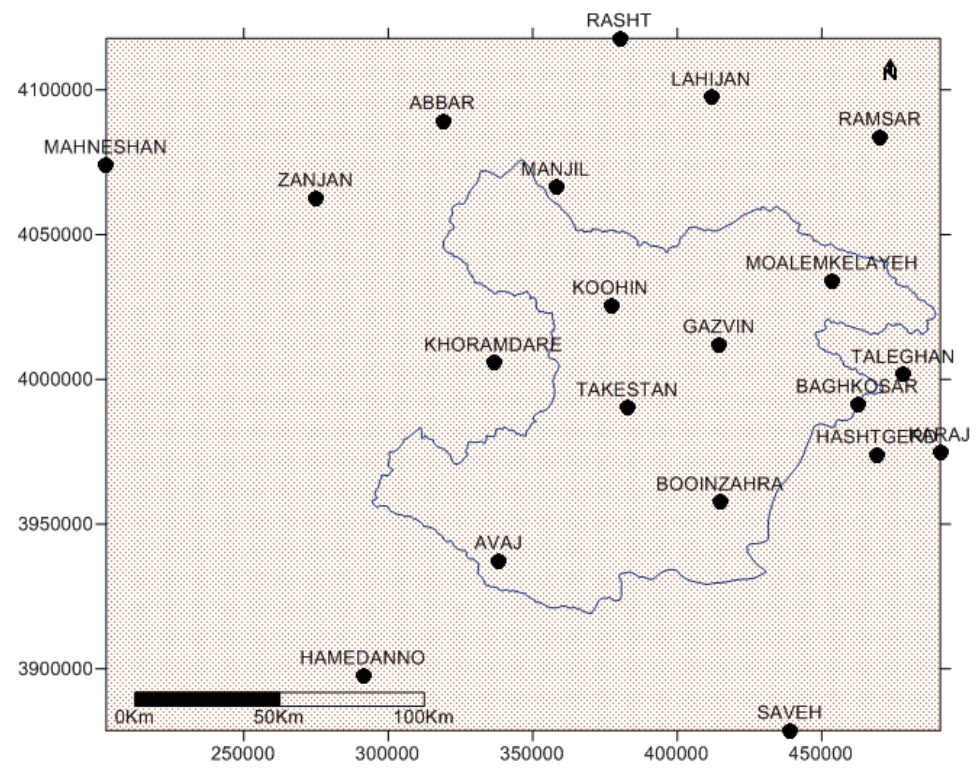

Figure 3. Geographical location of the stations employed

Table 1. Specifications of the stations employed

\begin{tabular}{|c|c|c|c|c|c|c|c|c|c|}
\hline No. & Station name & Longitude & Latitude & Height & No. & Station name & Longitude & Latitude & Height \\
\hline 1 & Manjil & $49 \quad 25$ & 3644 & 3.338 & 11 & Taleghan & $50 \quad 64$ & $\begin{array}{ll}36 & 10\end{array}$ & 1857 \\
\hline 2 & Ramsar & $50 \quad 40$ & $36 \quad 54$ & -20 & 12 & Zanjan & $48 \quad 29$ & 3641 & 1663 \\
\hline 3 & Gazvin & $50 \quad 03$ & $36 \quad 15$ & 2.1279 & 13 & Mahneshan & $47 \quad 40$ & 3646 & 1282 \\
\hline 4 & Takestan & $49 \quad 42$ & 36 & 4.1283 & 14 & Abbar & $48 \quad 58$ & 3656 & 703 \\
\hline 5 & Boin zahra & $50 \quad 04$ & 35 & 1282 & 15 & Khoramdar & $49 \quad 11$ & $36 \quad 11$ & 1575 \\
\hline 6 & Koohin & $49 \quad 38$ & $\begin{array}{ll}36 & 22\end{array}$ & 1549 & 16 & Hashtgerd & $50 \quad 45$ & 3600 & 1613 \\
\hline
\end{tabular}




\begin{tabular}{lllllcllllllll}
7 & Avaj & 49 & 13 & 35 & 34 & $2034 / 9$ & 17 & Karaj & 50 & 54 & 35 & 55 & 5.1312 \\
8 & Moalem kel & 50 & 29 & 36 & 27 & 2.1629 & 18 & Saveh & 50 & 20 & 35 & 13 & 1108 \\
9 & Baghe koosar & 50 & 33 & 36 & 4 & 1225 & 19 & Hamedan & 48 & 43 & 35 & 12 & 7.1679 \\
10 & Lahijan & 50 & 01 & 37 & 12 & 2.34 & 20 & Rasht & 49 & 38 & 37 & 12 & 8.24 \\
\hline
\end{tabular}

The existing data were arranged in the form of $\mathrm{R}$ (location in rows and climatic variables in columns). The matrix of $20 * 28$ point data was selected for better demonstration of the borderlines of the climatic areas and location patterns (Masoudian, 2003) in the Kriging process - which is among the most precise geographical information interpolation method - was employed with cells $5 * 5$ kilometers in dimension (given the area of Qazvin province), with the matrix of 623* 28 in surfer software environment covering the entire province area which was used as the input for factor analysis (See Figure 4). Since the scales used for the measurement of the climatic elements are varied, the aforesaid array was standardized for obviating the need for the dimensional aspects of the data.

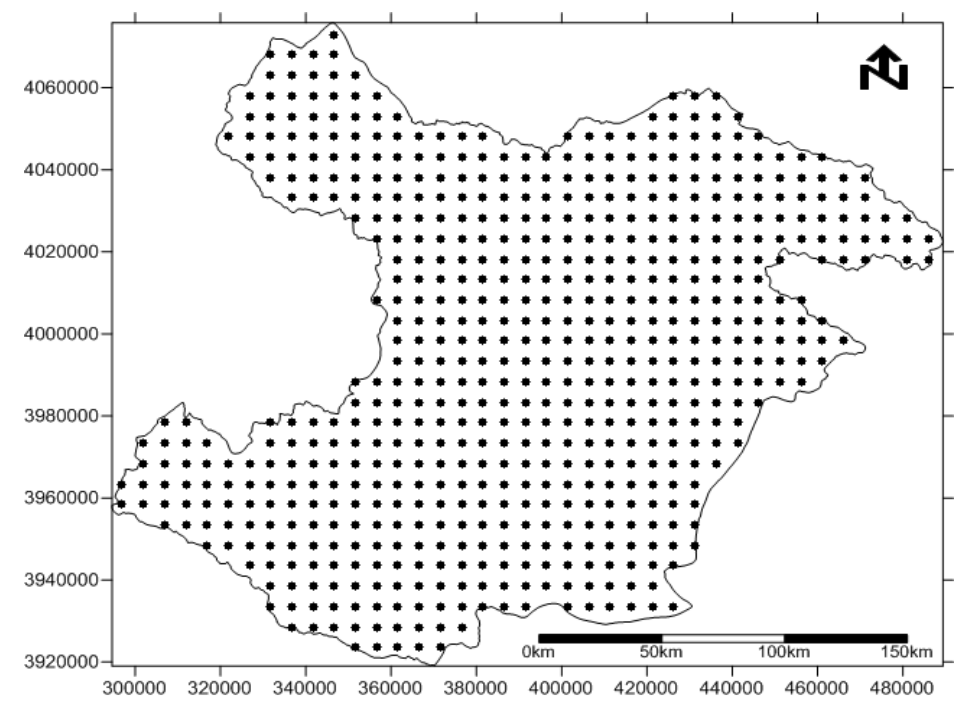

Figure 4. Knot points from interpolation

Factor analysis is a multivariate method of summarizing data. Put other way, it is a statistical technique that links a set of apparently irrelevant indicators under an imaginary pattern, and seeks to explain the correlative pattern that exists in a random vector for the minimum number of random variables in the name of factors (Pourtaheri, 2003). The closer the value of the internal correlation, the smaller will the number of factors involved (Dronekamp, 1991). In factor analysis, if the loaded number of variables of each indicator consists of the mean value on several factors, it will be difficult to interpret these factors. In order to achieve the desirable state, the factors will be rotated until a plain structure is achieved (Pourtaheri, 2003) and a preliminary arrangement is achieved and the initial arrangement will change into an arrangement which could be easy to interpret (Sarisaraf \& Rajaei, 1998). The rotation of factors takes place in either orthogonal rotation (non-correlative) or oblique rotation (correlative) (Ghayour \& Montazeri, 2004). In orthogonal rotation, the axes will turn cliockwise until the axes intersect two sets of variables and the factors are rotated until they form a right angle where negative factor loads are eliminated and factors achieve more loads and the initial variance is also maintained (Bakhtiari $\&$ Talebi, 2002).

One of the non-correlative factor rotation methods which is more common is referred to as the varimax rotation. This method assumes that the changeability of the factor can be measured by the square variance of the factor coefficients, i.e. $a^{2} 1 j, \ldots, a^{2} 2 j, \ldots, a 2 p j$. If the value of this variance is too high, the duration of the a2pj values will be near to zero. Therefore, the varimax rotation will maximize the set of these variances for all factors (Manly, 1994). 


\section{Discussion}

Performing factor analysis by main components and varimax rotation methods in SPSS environment on normalized arrangement of 38 climate variables showed that 9 factors are identifiable among them given the internal correlation that exists among them. Therefore, in factor analysis examination, the climate of the region is the result of the interaction among 9 different factors that explain 99.21 percent of the whole variance and total climate behavior of the province. Table 2 shows the significance of each of these factors and depicts the cliff diagram of the factors with respect to one another and is indicative of the fact that the first one and two factors have the highest slope which is reduced until it is rendered horizontal (See Figure 5).

Table 2. Factors relative significance

\begin{tabular}{cccccccccc}
\hline & Factor & Factor & Factor & Factor & Factor & Factor & Factor & Factor & Factor \\
& 1 & 2 & 3 & 4 & 5 & 6 & 7 & 8 & 9 \\
\hline \% variance & 19.35 & 67.21 & 04.13 & 71.8 & 39.6 & 35.4 & 03.4 & 65.3 & 13.2 \\
$\begin{array}{c}\text { \% cumulative } \\
\text { variance }\end{array}$ & 19.35 & 87.56 & 92.69 & 63.78 & 03.85 & 38.89 & 42.93 & 07.97 & 21.99 \\
\hline
\end{tabular}

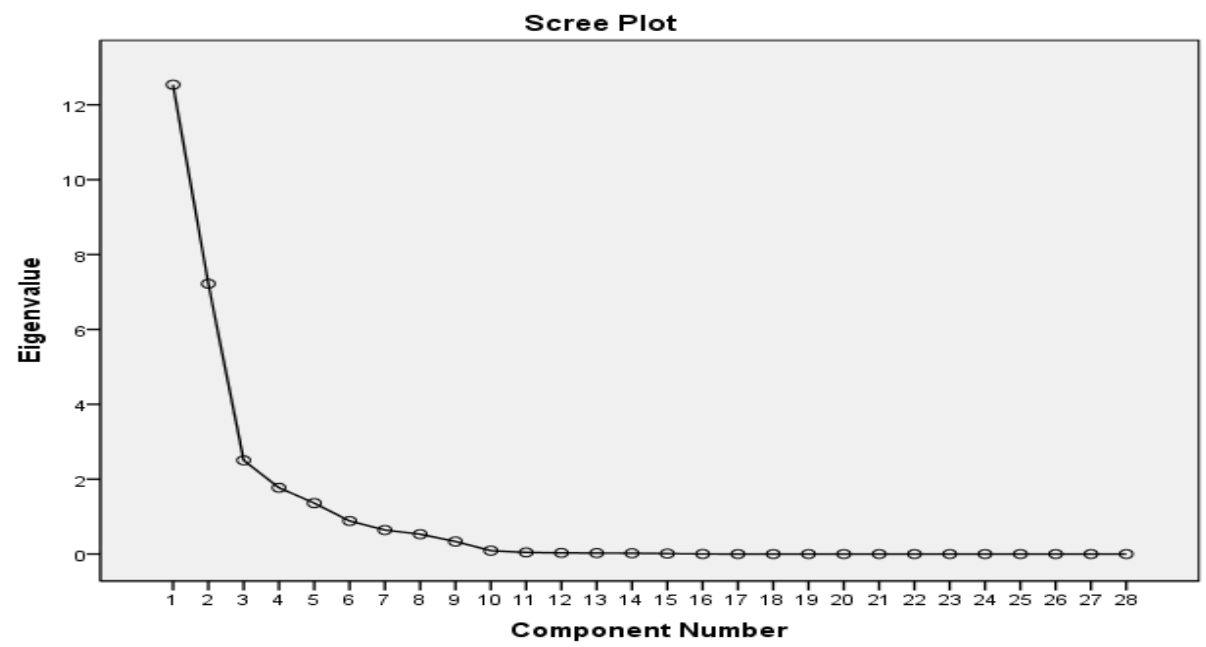

Figure 5. Cliff diagram of the extracted factors

Thus, using factor analysis the following procedure was covered:

a) Recognition of the main factors affecting the climate of the region under study in terms of climatic elements $(623 * 28)$

b) Preservation of the main factors that were identified on the basis of explaining over one percent and elimination of the smaller components

c) Formation of the arrangement of the loadings of the main factors $28^{*} 9 \mathrm{~km}$ in dimensions that actually weigh each climatic elements within factors

The arrangement of the scores of the main factors $623 * 9$ in dimensions that show the place value of the climate elements on each of the factors which can be mapped by means of the plotting software. These maps represent the main arrangements of the climate elements by the order of importance.

The first factor accounts for 35\% of data variance (see Table 2) and is in positive relation with temperature lows, station pressure, average dry temperature, saturated vapor pressure, number of precipitation days, average relative humidity and in negative relations with number of stormy and dusty days, temperature highs, total monthly precipitation and days with precipitation over $10 \mathrm{~mm}$ (See Table 3). Therefore it can be referred to as temperature-humidity factor, and in fact, temperature and humidity are the most important elements of the climate that constitute the structure of the province climate which lies mostly in the central and southern parts of the province (See Figures 6 and 7). 


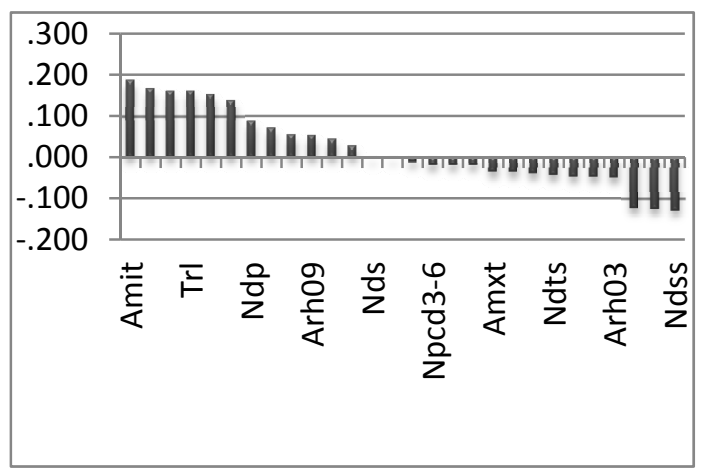

Figure 6. First factor load distribution

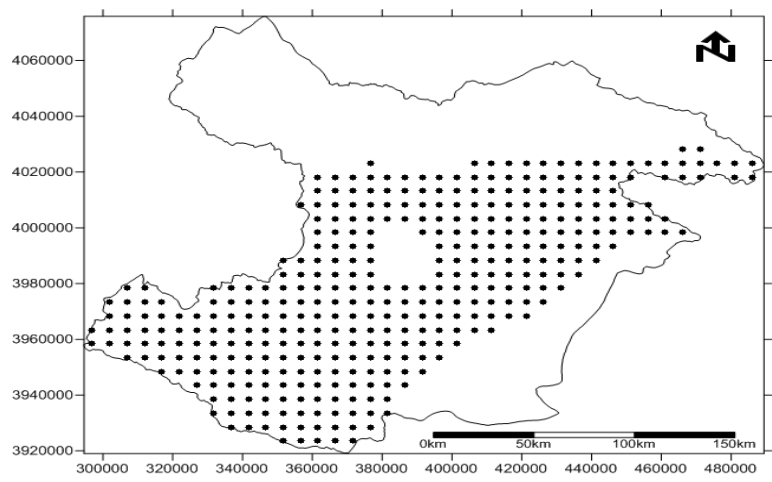

Figure 7. Place arrangement of first factor scores

Second factor is in positive relation with maximum 24-h precipitation, total monthly precipitation, number of precipitation days and over-1 and over-10 mm precipitation days, number of frost days, number of cloudy days, and humidity 09 and 15 days and in negative relations with the number of stormy days and lightning days, relative humidity 3 and temperature family which explains the $21.67 \%$ data variance. This can be called precipitation-humidity factor (See Figures 8 and 9).

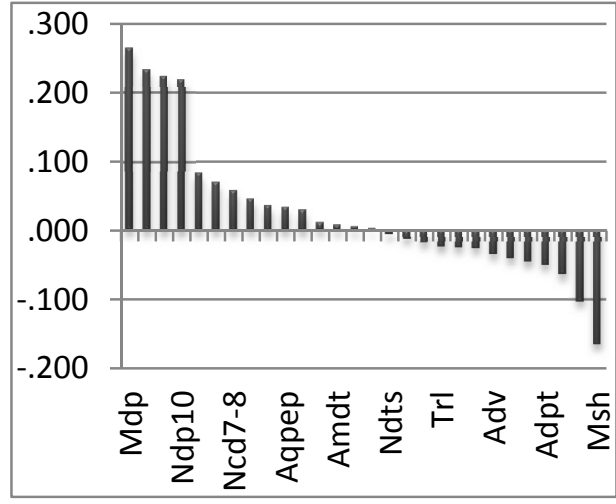

Figure 8. Second factor load distribution

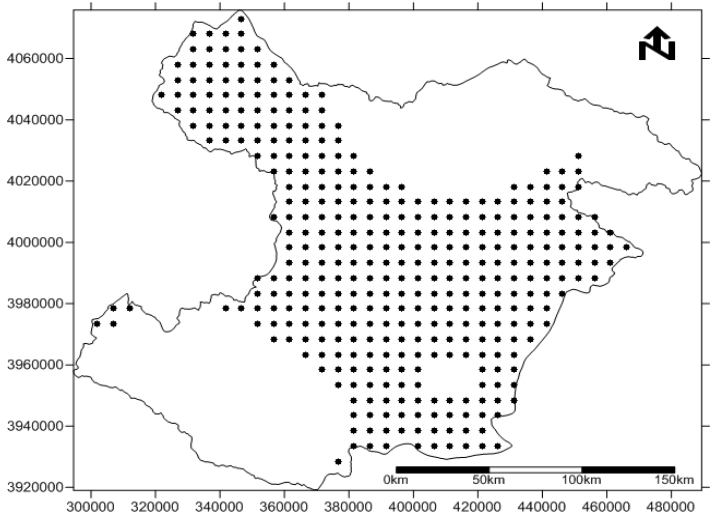

Figure 9. Place arrangement of second factor scores

The third factor that accounts for the $13.04 \%$ variance is positively related to the number of cloudy days, 3-6 and7-8, number of frost days, and days with more than $1 \mathrm{~mm}$ precipitation, saturated vapor pressure, and humidity elements and negatively related to the number of precipitation days, temperature highs, average temperature highs, maximum 24 hour precipitations and total sunny hour which can be referred to as cloud-temperature factor (see Figures 10 and 11).

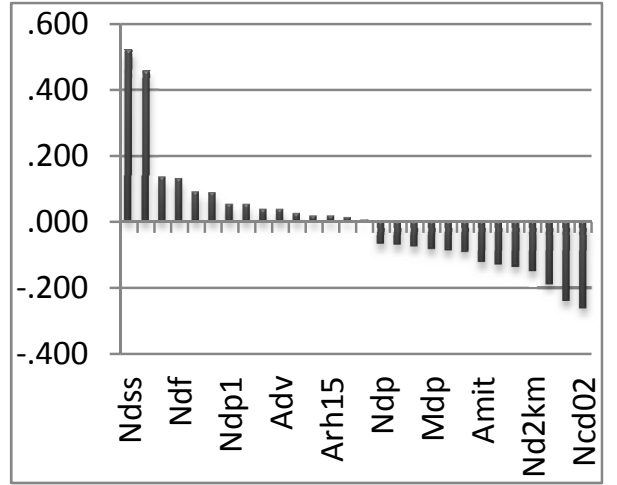

Figure 10. Load distribution of the third factor

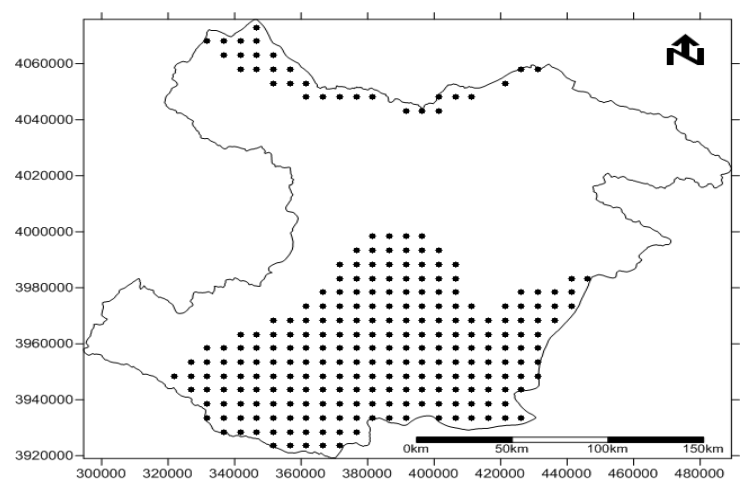

Figure 11. Place arrangement of the third factor scores 
The fourth factor is positively related to precipitation days, number of sunny hours, average relative humidity, average vapor pressure, number of 0-2 cloudy days, average dew temperature and breeze, and negatively related to the number of stormy and dusty days, number of stormy days with lightning, average daily temperature, humidity family, and temperature highs accounting for 8.71 percent of data variance (see Figures 12 and 13).

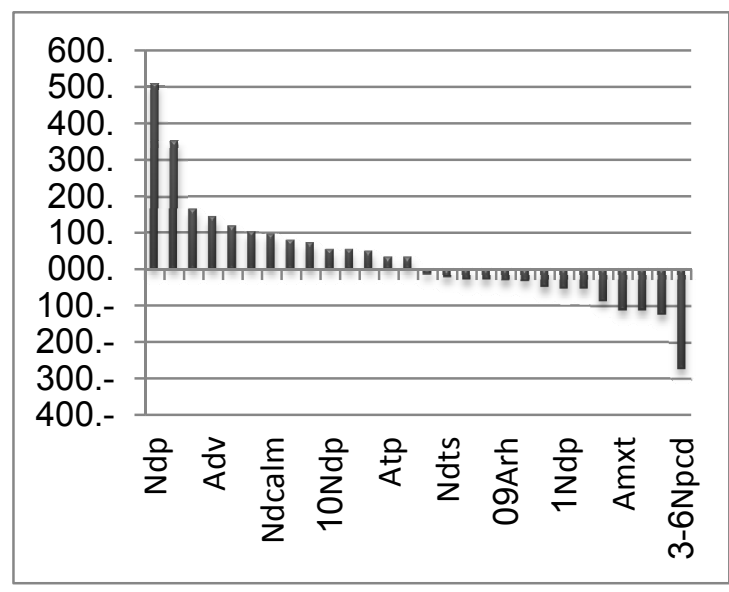

Figure 12. The fourth factor loads distribution

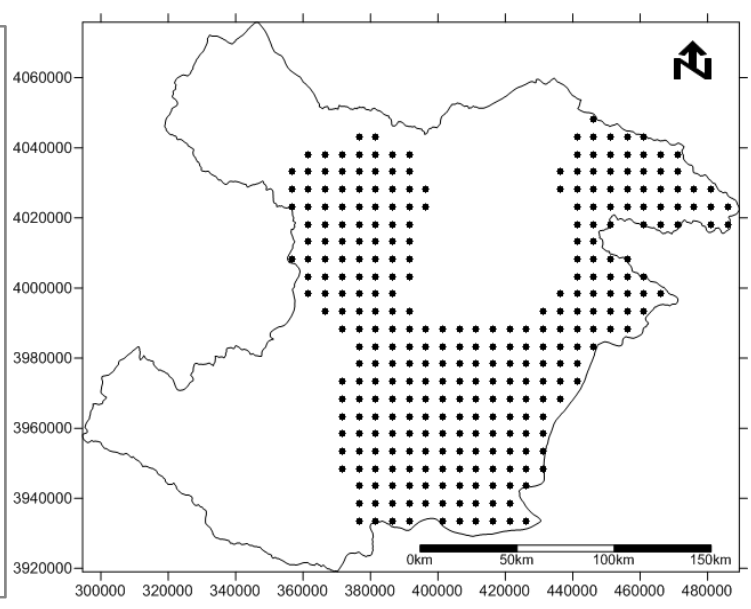

Figure 13. Fourth factor scores place arrangement

The fifth factor is positively related to breeze, average temperature high, average daily temperature, temperature highs, number of 0-2 cloudy days, days with precipitation over $10 \mathrm{~mm}$ and negatively related to the number of frosty days, snowy days and 3-6 cloudy days, average temperature lows, average saturated vapor pressure, relative humidity of $90 \%$ and pressure at the station, accounting for the $6.39 \%$ of variance (see Figures 14 and 15).

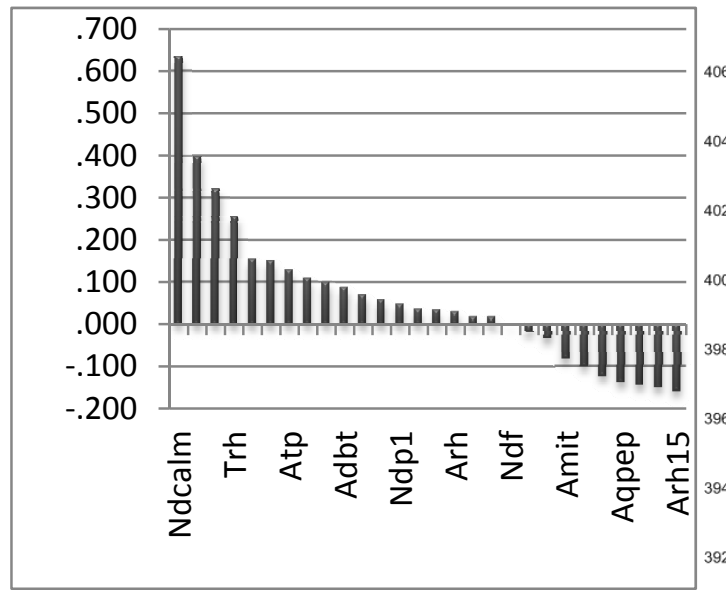

Figure 14. Fifth factor load distribution

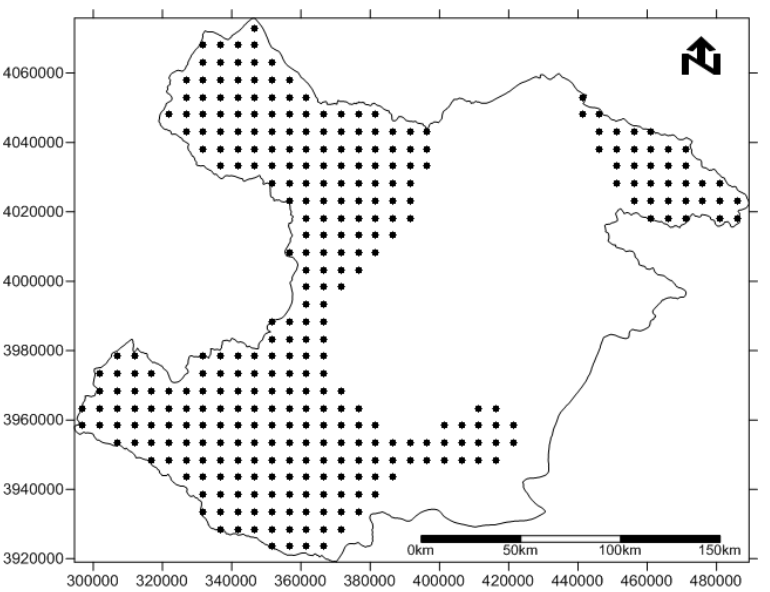

Figure 15. Place arrangement of the Fifth factor scores

In the sixth factor, most of the weight goes to the positively related variables of the number of days with storms and lightning, temperature highs, low relative humidity and maximum 24-hour precipitation and number of days with less than 2-kilometer visibility and negatively related with relative humidity, temperature lows and average due point which are indicative of atmospheric instability accounting for the $4.35 \%$ of data variance (see Figures 16 and 17). These factors totally account for 90 percent of data variance. For the sake of brevity the other three factors are ignored. 


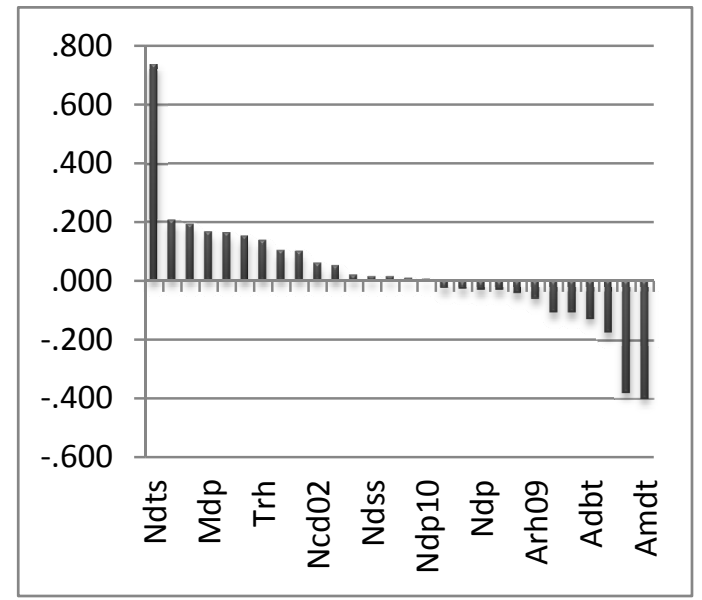

Figure 16. Sixth factor load distribution

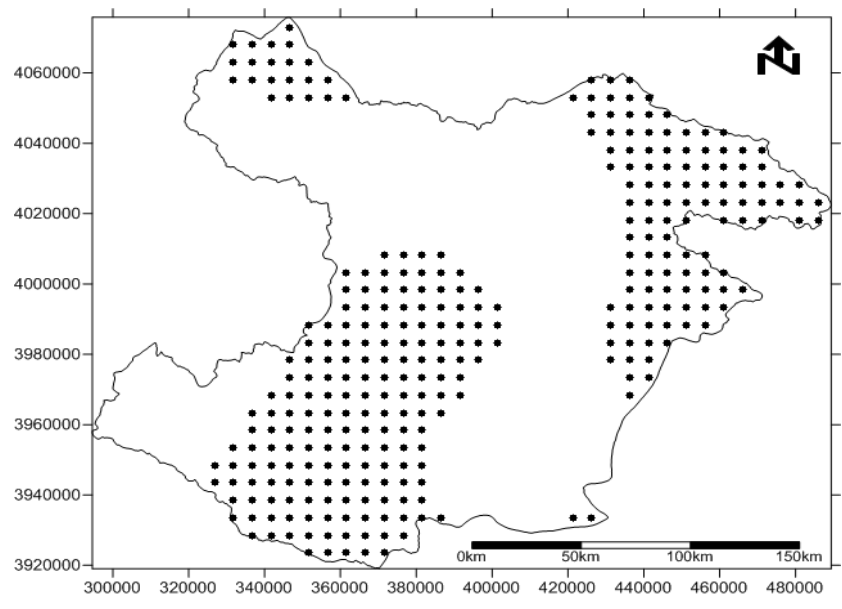

Figure 17. Place arrangement of the sixth factor scores

Table 3. Values of factor loads on climatic elements

\begin{tabular}{|c|c|c|c|c|c|c|c|c|c|c|}
\hline Climatic elements & & Factor 1 & Factor 2 & Factor 3 & Factor 4 & Factor 5 & Factor 6 & Factor 7 & Factor 8 & Factor 9 \\
\hline $\begin{array}{l}\text { Average dry bulb } \\
\text { temperature }\end{array}$ & ADB.T & 15.0 & 04.0 & 191.-0 & 31.0 & 86.0 & $129 .-0$ & $057 .-0$ & 075.0 & $160 .-0$ \\
\hline $\begin{array}{l}\text { Average dew point } \\
\text { temperature }\end{array}$ & AD.PT & 159.0 & $52 .-0$ & 238.0 & 101.0 & 33.0 & 107.-0 & 260.0 & 223.0 & 122.0 \\
\hline $\begin{array}{c}\text { Average saturated } \\
\text { vapor pressure }\end{array}$ & AD.V & 135.0 & $35 .-0$ & 36.0 & 141.0 & 101.0 & 177.-0 & 101.-0 & 009.-0 & 089.-0 \\
\hline $\begin{array}{l}\text { Average daily } \\
\text { temperature }\end{array}$ & AMDT & $20 .-0$ & 07.0 & 23.0 & $30 .-0$ & 319.-0 & 400.0 & $401 .-0$ & 044.0 & 043.0 \\
\hline $\begin{array}{c}\text { Average temp. } \\
\text { lows }\end{array}$ & AMIT & 185.0 & $27 .-0$ & $122 .-0$ & 52.0 & $83 .-0$ & 019.-0 & 201.0 & 106.-0 & 206.-0 \\
\hline $\begin{array}{l}\text { Average temp. } \\
\text { highs }\end{array}$ & AMXT & $37 .-0$ & 35.0 & 075.0 & $113 .-0$ & 396.0 & 204.0 & 110.0 & 056.-0 & $040 .-0$ \\
\hline $\begin{array}{c}\text { Average station } \\
\text { pressure }\end{array}$ & $\begin{array}{c}\text { AQPE } \\
P\end{array}$ & 165.0 & 32.0 & 51.0 & 71.0 & 139.-0 & 101.0 & $273 .-0$ & $248 .-0$ & $372 .-0$ \\
\hline $\begin{array}{c}\text { Average relative } \\
\text { humidity }\end{array}$ & $\mathrm{ARH}$ & 43.0 & 18.-0 & $37 .-0$ & 162.0 & 028.0 & 032.-0 & 019.-0 & 134.0 & 479.0 \\
\hline $\begin{array}{l}\text { Total monthly } \\
\text { precipitation }\end{array}$ & ATP & $13 .-0$ & 232.0 & $89 .-0$ & 32.0 & 128.0 & 010.0 & 173.-0 & 117.0 & 003.-0 \\
\hline $\begin{array}{c}\text { Lowest } \\
\text { temperature }\end{array}$ & TRL & 158.0 & $25 .-0$ & 004.0 & 47.0 & 151.-0 & $027 .-0$ & $055 .-0$ & 025.0 & $276 .-0$ \\
\hline $\begin{array}{c}\text { Highest } \\
\text { temperature }\end{array}$ & TRH & 04.-0 & $46 .-0$ & 71.0 & $50 .-0$ & 255.0 & 135.0 & 009.0 & 281.0 & 071.-0 \\
\hline 3-6 cloudy days & $\begin{array}{l}\text { NPCD } \\
3.6\end{array}$ & $20 .-0$ & $26 .-0$ & 134.0 & $273 .-0$ & $35 .-0$ & 139.-0 & $142 .-0$ & 201.0 & $164 .-0$ \\
\hline $\begin{array}{l}\text { Nr of days with } \\
\text { storm \& lightning }\end{array}$ & N.DTS & $44 .-0$ & $06 .-0$ & 011.0 & 023.0 & 34.0 & 735.0 & 136.0 & 070.0 & 056.0 \\
\hline Nr. of snowy days & N.DSS & $130 .-0$ & $65 .-0$ & 519.0 & $113 .-0$ & 018.-0 & 014.0 & 103.-0 & $239 .-0$ & $237 .-0$ \\
\hline $\begin{array}{c}\text { Nr. of stormy \& } \\
\text { dusty days }\end{array}$ & N.DS & $03 .-0$ & $103 .-0$ & 131.-0 & $014 .-0$ & 69.0 & 050.0 & 931.0 & 142.0 & 101.0 \\
\hline $\begin{array}{l}\text { Nr. of days with } \\
\text { over } 10 \mathrm{~mm} \\
\text { precipitation }\end{array}$ & $\begin{array}{c}\text { N.DP1 } \\
0\end{array}$ & $21 .-0$ & 218.0 & $135 .-0$ & 52.0 & 150.0 & 007.0 & 122.- 0 & 241.0 & 130.0 \\
\hline $\begin{array}{l}\text { Nr. of days with } \\
\text { over } 1 \mathrm{~mm} \\
\text { precipitation }\end{array}$ & N.DP1 & $41 .-0$ & 222.0 & 53.0 & $55 .-0$ & 046.0 & 014.0 & $220 .-0$ & 033.-0 & 286.-0 \\
\hline Nr. of days with & N.DP & 86.0 & 10.0 & $66 .-0$ & 507.0 & 057.0 & $031 .-0$ & 047.-0 & 030.-0 & 224.0 \\
\hline
\end{tabular}




\begin{tabular}{|c|c|c|c|c|c|c|c|c|c|c|}
\hline precipitation & & & & & & & & & & \\
\hline Nr. of frosty days & $\mathrm{NDF}$ & $125 .-0$ & 82.0 & 129.0 & $91 .-0$ & $002 .-0$ & 099.0 & $277 .-0$ & 114.0 & $292 .-0$ \\
\hline \multirow[t]{2}{*}{ Calm wind } & N.DC & 124.-0 & 69.0 & 88.0 & 94.0 & 634.0 & 150.0 & 160.0 & 013.0 & 212.-0 \\
\hline & ALM & & & & & & & & & \\
\hline Nr. of days with & NDVL & $48 .-0$ & 44.0 & $151 .-0$ & $55 .-0$ & 108.0 & 163.0 & 123.0 & 878.0 & 044.0 \\
\hline $\begin{array}{c}\text { shorter than } 2 \mathrm{~km} \\
\text { visibility }\end{array}$ & \multicolumn{10}{|c|}{ visibility } \\
\hline Nr. of 7-8 cloudy & NCD7. & 53.0 & 57.0 & 88.0 & 76.0 & 016.0 & 042.0 & 117.0 & 137.-0 & $359 .-0$ \\
\hline days & 8 & & & & & & & & & \\
\hline Nr. of $0-2$ cloudy & NCD0. & $49 .-0$ & $42 .-0$ & $261 .-0$ & 115.0 & 154.0 & 052.0 & 158.0 & 167.0 & 648.0 \\
\hline days & 2 & & & & & & & & & \\
\hline Nr. of sunny hours & MSIH & 26.0 & 165.-0 & 88.0 & 349.0 & 017.0 & 379.-0 & 014.-0 & 445.0 & 096.0 \\
\hline Maximum & MDP & $37 .-0$ & 263.0 & $82 .-0$ & 126.-0 & 097.0 & 164.0 & 084.-0 & 111.0 & 003.0 \\
\hline \multicolumn{11}{|l|}{ 24-h precipitation } \\
\hline Average 0.3 & ARHO & $50 .-0$ & 12.0 & 455.0 & 31.0 & 145.0 & 191.0 & 262.-0 & 479.-0 & 350.0 \\
\hline relative humidity & 3 & & & & & & & & & \\
\hline Average 0.9 & ARHO & 51.0 & 02.0 & 17.0 & $33 .-0$ & 123.-0 & $060 .-0$ & 107.0 & 137.-0 & 589.0 \\
\hline relative humidity & 9 & & & & & & & & & \\
\hline Average 15 & ARH1 & 70.0 & 29.0 & 16.0 & $35 .-0$ & $160 .-0$ & 026.-0 & 137.-0 & 090.0 & 370.0 \\
\hline relative humidity & 5 & & & & & & & & & \\
\hline
\end{tabular}

\section{Cluster Analysis}

At this stage, in order to obtain climatic location clusters, location scores, of 9 components resulting from factor analysis underwent cluster analysis so that all cells that are similar in terms of 9 main factor scores form the members of one single climatic area. There are two basic steps in a cluster analysis: first, calculation of the degree of similarity; and the second step is to group the people by degree of similarity. The Euclidian space is used to calculate the degree of similarity in climatologic studies (Masoudian, 2003) and the resulting matrix will be a symmetrical one the end of diameters of which there are zeroes and it is horizontally symmetrical. There are various ways in the groupings of the observations on the basis of the spaces between them such as sequential and hierarchical and agglomerative groupings. In the hierarchical method which has been used in this study, the observations are merged two by two in proportion with the increase or decrease in spaces between them so that in the end all of them fall into a large group. After the measurement of the degree of similarity, the merging method should be used that create the highest degree of similarity, including the Ward method that is commonly used in climatologic studies in which a member is assigned to a cluster the variance of which falls in the cluster where variance within the cluster is the least value possible so that homogeneity increases within the group. Thus groups are formed that enjoy more internal cohesiveness (Masoudian, 2006).

As such a mixed hierarchical-agglomerative was carried out using the ward method on the arrangements of the 9 factor scores as $623 * 2$ and on the basis of the tree diagram 9 climatic zones were identified for Qazvin province (fig. 18). Each climatic zone shows a special mix of the main factor scores (table 4). Therefore each cell falls in one of the climatic zones on the basis of the value of their scores (Montazeri, 2003). 


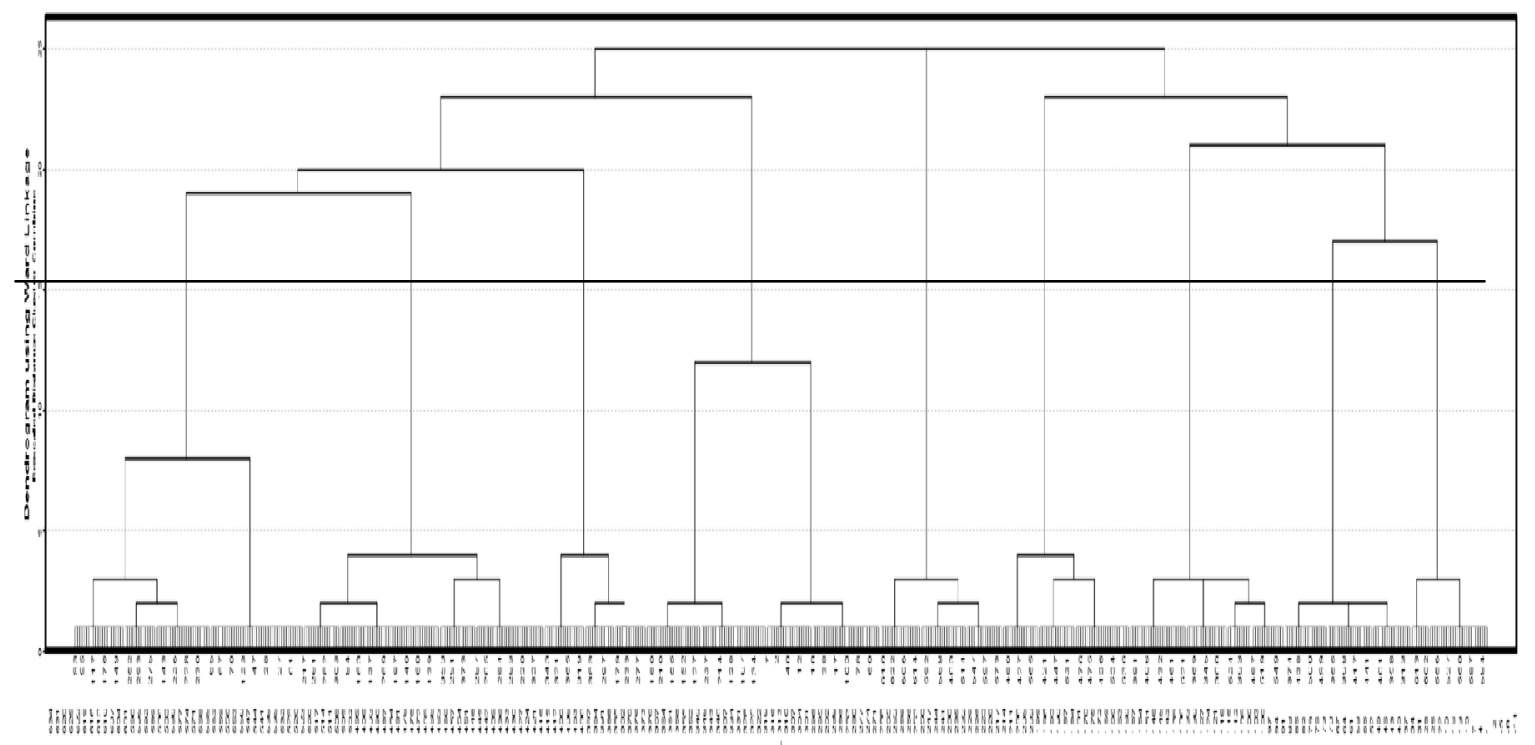

Figure 18. Climatic diagram of Qazvin Province

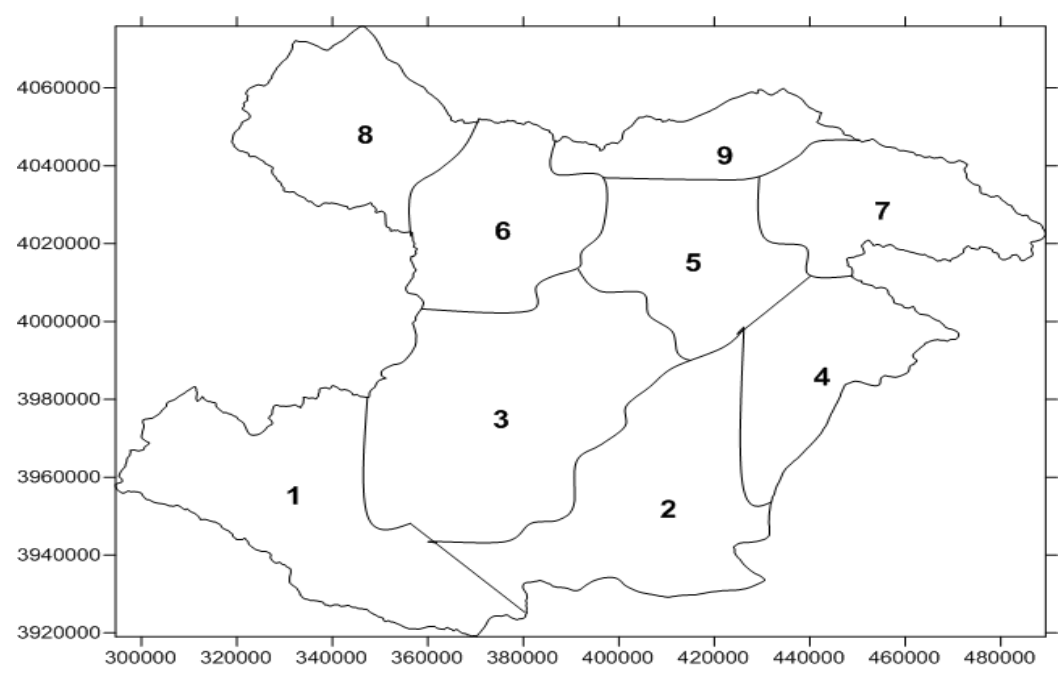

Figure 19. Location segregation of the climatic zones of Qazvin Province

The zones segregated in the past are as follows:

\section{Showery and Ultra-cold Avaj Sub-climate}

This area which covers southern and southwestern heights of the province, that is the Avaj and Shahid Abad, covers $16.5 \%$ of the province area. This area has the minimum average temperature $\left(11.93^{\circ} \mathrm{C}\right)$ and the lowest average temperature lows: $5.29{ }^{\circ} \mathrm{C}$ and lowest temperature $\left(-17.48{ }^{\circ} \mathrm{C}\right)$ and lowest vapor pressure among in the region. The total annual precipitation of the area is $345.09 \mathrm{~mm}$, and the greatest number of frosty days (107.58 days) that is more than three months long. Due to low vapor holding capacity the least relative humidity is found in this area, and migration from this area toward the capital city of the province is on the rise.

\section{Mild and low-precipitation zone of Bouein Zahra and Namakzar Swamp sub-climate}

This area which covers $16.22 \%$ of the province is located in the South East of the province. The average daily temperature of this area is $16.04{ }^{\circ} \mathrm{C}$ which is indicative of a mild relative temperature. The low precipitation of $262.33 \mathrm{~mm}$ explains the dry weather due to its being distant from the sea, and the predominance of the high pressure of adjacent tropical weather in hot seasons, and the penetration of the next-to-polar over-precipitated in the cold season has made dry weather Continental conditions prevail in this area. The highest average of maximum temperature is seen in this area at $21.96{ }^{\circ} \mathrm{C}$. The least number of snowy days is 7.83 days and the least number of the fully cloudy days and the least number of the precipitation days is 36.66 days in this area the 
reduced cloudiness in this region can be attributed to the transparency of the atmosphere in the east of Qazvin and reflection away of the sun rays after hitting the surface of the earth (Inanlou, 2003). This area is of increased evaporation power due to its being subject to local hot and dry winds that originate from the central plateau.

\section{Mild and relatively low-precipitation sub-climate of Takestan and western part of the province}

This area covers $17 \%$ of the province area and is the largest climatic area of the province. This area is the interface between the two northern mountainous area and the southern part of the province where the most abundant agricultural produce, grapes are produced in the vineyards of this region. This very vegetation has led to the lowest number of the stormy and dusty days (5.45 days) in this area. The average daily temperature high is $16.49{ }^{\circ} \mathrm{C}$ and the average annual precipitation rate is $27.50 \mathrm{~mm}$. The exposure of this area to the hot winds blowing in autumn leads to early ripening of garden products, especially grapes.

\section{Semi-hot and relatively low-precipitation sub-climate of Abyek and east of Qazvin plain}

The northern part of this area is bordered by Palang mountains, Peyghamber Kouh and its southern part is salty swarms. The average daily temperature in this area is $18.61{ }^{\circ} \mathrm{C}$ which is the highest temperature among the areas with the average annual precipitation rate of $273.88 \mathrm{~mm}$. The recorded average temperature high of $39.82{ }^{\circ} \mathrm{C}$ is seen in this area. Due to the swarm and salty nature of the land and its lost fertility in the southern parts, the population is sporadically distributed in the region. The city of Abyek is the only major city in this area. In the north the area is milder with higher rainfalls. This area covers 7.23 percent of the province area.

\section{Qazvin mild and semi-dry mountain skirt sub-climate}

This area is the interface between the Qazvin plain and the northern mountainous areas. The average daily temperature in this area is $15.27{ }^{\circ} \mathrm{C}$ and amount of precipitation is $335.68 \mathrm{~mm}$. This area covers 8.89 percent of the province capital in climate and consists of the capital of the province, the city of Qazvin, Alborz Industrial town and its residential area, the city of Alvand, which is the second most populous city in the province, as well as a number of village-towns and newly built cities.

\section{Kouhin semi-cold and semi-dry sub-climate}

This area which is located between 1000 and 2500 meters in altitude covers 10.92 percent of the province. Average daily temperature of this area is $14.45{ }^{\circ} \mathrm{C}$ which is the least daily temperature after Avaj mountainous area, and the average annual precipitation rate is $305.43 \mathrm{~mm}$. Due to fogginess this area has the greatest number of days with less than 2 kilometer visibility ( 47.22 days) and naturally, the greatest number of semi-cloudy days (145 days).

\section{Semi-cold and semi-high-precipitation sub-climate of East Alamout}

This area which is located to the north-east of the province covers $5.45 \%$ of the climate territory. This area hosts the 4150-m Siyalan mountain peak. The area has the second highest precipitation rate in the province. The average daily temperature of this region is $14.71{ }^{\circ} \mathrm{C}$ and the average saturated vapor pressure is 9.14 . The area has the biggest number of snowy days (33.04), and the smallest number of cloudy days due to its being mountainous, which has led to the emanation of Shahroud and its branches such as Taleghan Roud and Alamout Roud as well as feeding water tables in the north of Qazvin plain. These make this area unique. The semi-thick vegetation has given the area a very beautiful sight, which is among the tourist attraction hubs in Iran.

\section{Manjil Dam Lake mild low precipitation and Tarom Sofla subclimate}

Coverng $8.98 \%$ of the province, this area is located to the north-west of the province at the Tarom Sofla region. This region hosts the lowest points of the province with the area of 300 square meters around Manjil Dam Lake. The average daily temperature at this area in $15.3{ }^{\circ} \mathrm{C}$ and the amount of precipitation per year is $204.48 \mathrm{~mm}$. The average dew point in the area is $5.33{ }^{\circ} \mathrm{C}$ and the lowest number of 24 -h precipitation days (21.30 days) and the highest number of the more than $1 \mathrm{~mm}$ and $10 \mathrm{~mm}$ precipitation days and the highest number of stormy and lightning days are among the characteristics of this region. The totality of these factors has given a quasi-Mediterranean climate to this region and olive is the predominant agricultural product of the region.

\section{West Alamout and Razmian mild and semi-humid subclimate}

This sub-climate which covers $5.45 \%$ of the province area has the highest precipitation with the average annual precipitation rate of $586.89 \mathrm{~mm}$. the highest number of precipitation days in this sub-climate is 62.57 and the highest number of 24-h precipitation days is 44.93, and the highest dew point and water evaporation temperatures are $5.96{ }^{\circ} \mathrm{C}$ and $10.74{ }^{\circ} \mathrm{C}$ respectively. The high relative humidity and the smallest number of cloudless days is evidence that the region is humid with high precipitation and its climatic elements conform to those of the mountainous areas of the region. 
Table 4. Average climate element values in Qazvin Province Sub-climates

\begin{tabular}{|c|c|c|c|c|c|c|c|c|c|}
\hline $\begin{array}{l}\text { Climatic } \\
\text { elements }\end{array}$ & Zone 1 & Zone 2 & Zone 3 & Zone 4 & Zone 5 & Zone 6 & Zone 7 & Zone 8 & Zone 9 \\
\hline Avg dry temp. & 39.12 & 74.14 & 20.14 & 49.14 & 12.14 & 25.14 & 96.13 & 28.15 & 04.15 \\
\hline Avg dew point & $34 .-0$ & 01.3 & 66.1 & 86.3 & 11.3 & 57.3 & 90.3 & 33.5 & 96.5 \\
\hline $\begin{array}{l}\text { Avg daily } \\
\text { tempe. }\end{array}$ & 93.11 & 04.16 & 49.16 & 61.18 & 27.15 & 45.14 & 71.14 & 3.15 & 10.15 \\
\hline Avg. temp. lows & 29.5 & 91.7 & 83.6 & 24.7 & 56.7 & 74.7 & 39.8 & 37.9 & 56.9 \\
\hline $\begin{array}{l}\text { Avg.temp. } \\
\text { highs }\end{array}$ & 49.17 & 96.21 & 37.20 & 68.21 & 11.21 & 74.19 & 84.19 & 97.20 & 36.20 \\
\hline Lowest temp. & $48 .-17$ & $51 .-13$ & $03 .-14$ & $61 .-13$ & $03 .-12$ & $97 .-9$ & $89 .-10$ & $66 .-7$ & $73 .-7$ \\
\hline Highest temp. & 50.36 & 75.39 & 07.39 & 82.39 & 80.39 & 82.39 & 73.37 & 27.40 & 28.38 \\
\hline $\begin{array}{l}\text { Avg saturated } \\
\text { vapor pressure }\end{array}$ & 39.6 & 46.7 & 49.7 & 70.8 & 49.8 & 85.8 & 14.9 & 03.10 & 74.10 \\
\hline $\begin{array}{l}\text { Avg station } \\
\text { pressure }\end{array}$ & 29.816 & 89.865 & 60.855 & 75.837 & 86.866 & 90.873 & 05.848 & 60.914 & 05.900 \\
\hline $\begin{array}{c}\text { Max nr of 24-h } \\
\text { prec. days }\end{array}$ & 95.33 & 09.33 & 24.28 & 62.29 & 05.31 & 26.29 & 13.40 & 30.21 & 93.49 \\
\hline $\begin{array}{c}\text { Total monthly } \\
\text { prec. }\end{array}$ & 09.345 & 33.262 & 50.272 & 88.273 & 68.335 & 43.305 & 31.416 & 48.204 & 89.586 \\
\hline $\begin{array}{l}\text { Nr. of }>1 \mathrm{~m} \\
\text { prec. days }\end{array}$ & 52.52 & 57.44 & 84.46 & 10.44 & 46.49 & 27.48 & 60.57 & 60.40 & 76.63 \\
\hline $\begin{array}{c}\mathrm{Nr} \text {. of }>10 \mathrm{~mm} \\
\text { prec. days }\end{array}$ & 27.10 & 49.7 & 79.7 & 39.8 & 96.9 & 28.9 & 11.12 & 63.5 & 56.17 \\
\hline $\begin{array}{c}\text { Nr. of Prec. } \\
\text { days }\end{array}$ & 48.59 & 66.36 & 48.46 & 63.37 & 11.59 & 71.40 & 57.39 & 07.57 & 57.62 \\
\hline $\begin{array}{l}\text { Nr. of stormy \& } \\
\text { lightning dyas }\end{array}$ & 04.21 & 11.25 & 46.21 & 43.19 & 28.26 & 21.26 & 09.16 & 99.26 & 98.19 \\
\hline $\begin{array}{l}\text { Nr. of snow } \\
\text { days }\end{array}$ & 27.11 & 83.7 & 37.11 & 70.17 & 21.18 & 37.17 & 04.33 & 16 & 59.16 \\
\hline $\begin{array}{l}\text { Nr. of Stormy \& } \\
\text { dusty days }\end{array}$ & 79.9 & 49.7 & 45.5 & 28.10 & 82.9 & 04.8 & 31.17 & 41.8 & 63.11 \\
\hline $\begin{array}{c}\text { Nr. of frosty } \\
\text { days }\end{array}$ & 58.107 & 63.75 & 41.89 & 46.56 & 07.72 & 03.69 & 99.57 & 25.48 & 83.44 \\
\hline Calm wind & 12.594 & 88.701 & 93.735 & 75.1005 & 15.1338 & 50.614 & 90.1074 & 46.851 & 13.1126 \\
\hline $\begin{array}{l}\text { Nr. of }<2 \mathrm{~km} \\
\text { visib. days }\end{array}$ & 13.18 & 66.12 & 33.15 & 98.21 & 53.32 & 22.47 & 86.32 & 30.18 & 57.41 \\
\hline $\begin{array}{l}\text { Nr. of 0-2 } \\
\text { cloudy days }\end{array}$ & 55.204 & 05.203 & 37.196 & 95.197 & 81.183 & 77.173 & 02.151 & 43.177 & 31.153 \\
\hline $\begin{array}{l}\text { Nr. of 3-6 } \\
\text { cloudy days }\end{array}$ & 80.112 & 98.130 & 97.128 & 60.142 & 77.138 & 145 & 21.143 & 61.133 & 12.136 \\
\hline $\begin{array}{l}\text { Nr. of 7-8 } \\
\text { cloudy days }\end{array}$ & 19.44 & 77.33 & 74.37 & 46.39 & 12.55 & 84.44 & 47.74 & 22.51 & 75.79 \\
\hline $\begin{array}{l}\text { Nr. of sunny } \\
\text { hours }\end{array}$ & 17.2959 & 44.2585 & 14.2862 & 42.2746 & 06.2851 & 74.2775 & 24.2611 & 48.2826 & 97.2505 \\
\hline $\begin{array}{l}\text { Avg rel. } \\
\text { humidity }\end{array}$ & 56.47 & 27.49 & 84.48 & 42.55 & 34.54 & 49.54 & 47.54 & 81.55 & 27.61 \\
\hline $\begin{array}{c}\text { Avg rel } \\
\text { humidity03 }\end{array}$ & 48.65 & 03.68 & 69.66 & 89.71 & 57.70 & 01.71 & 12.71 & 71.72 & 45.74 \\
\hline $\begin{array}{c}\text { Avg rel } \\
\text { humidity09 }\end{array}$ & 75.38 & 61.42 & 26.39 & 87.46 & 83.40 & 12.43 & 07.47 & 63.43 & 08.50 \\
\hline $\begin{array}{c}\text { Avg rel } \\
\text { humidity15 }\end{array}$ & 71.44 & 31.49 & 17.47 & 47.52 & 90.48 & 94.53 & 88.52 & 12.52 & 68.58 \\
\hline
\end{tabular}




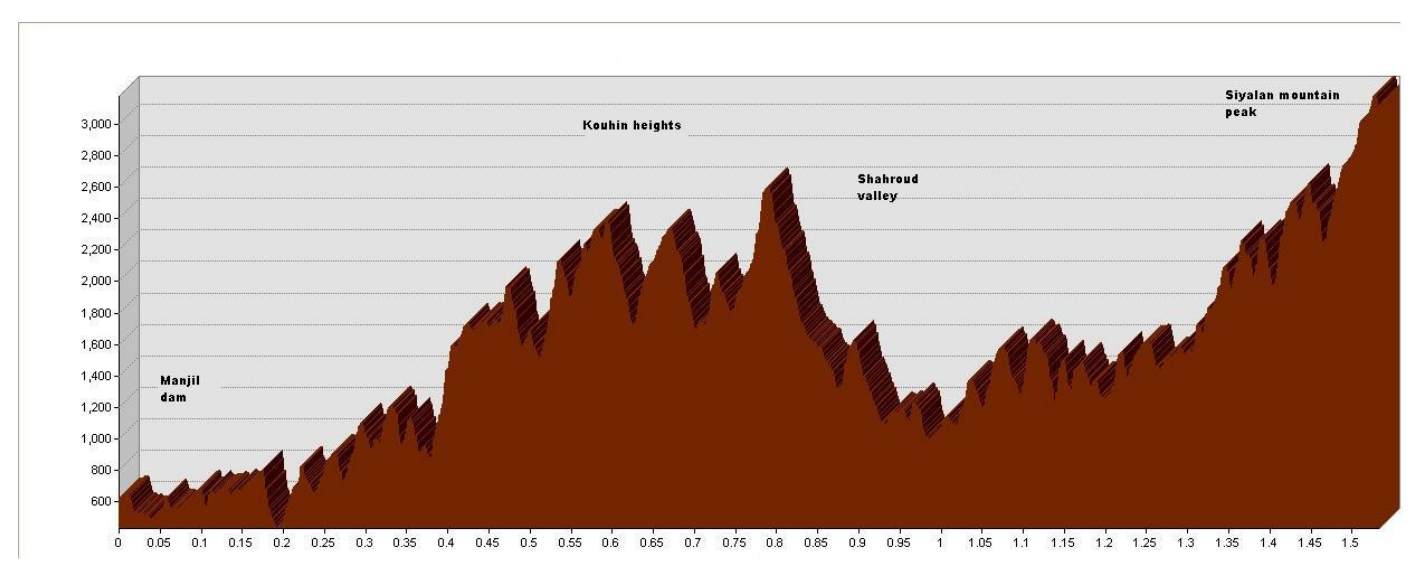

Figure 20. Manjil Dam Lake to Siyalan Mountain peak profile in Qazvin Province

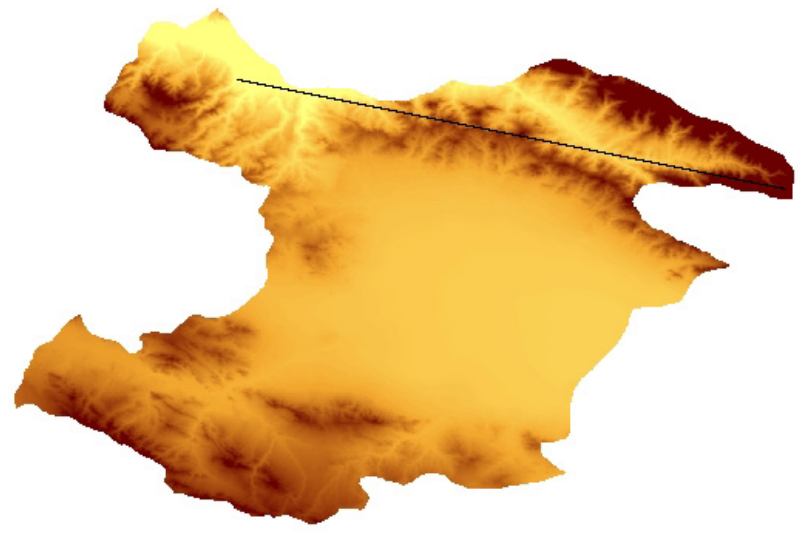

Figure 21. Manjil Dam to Siyalan Mountain peak cross sectional profile

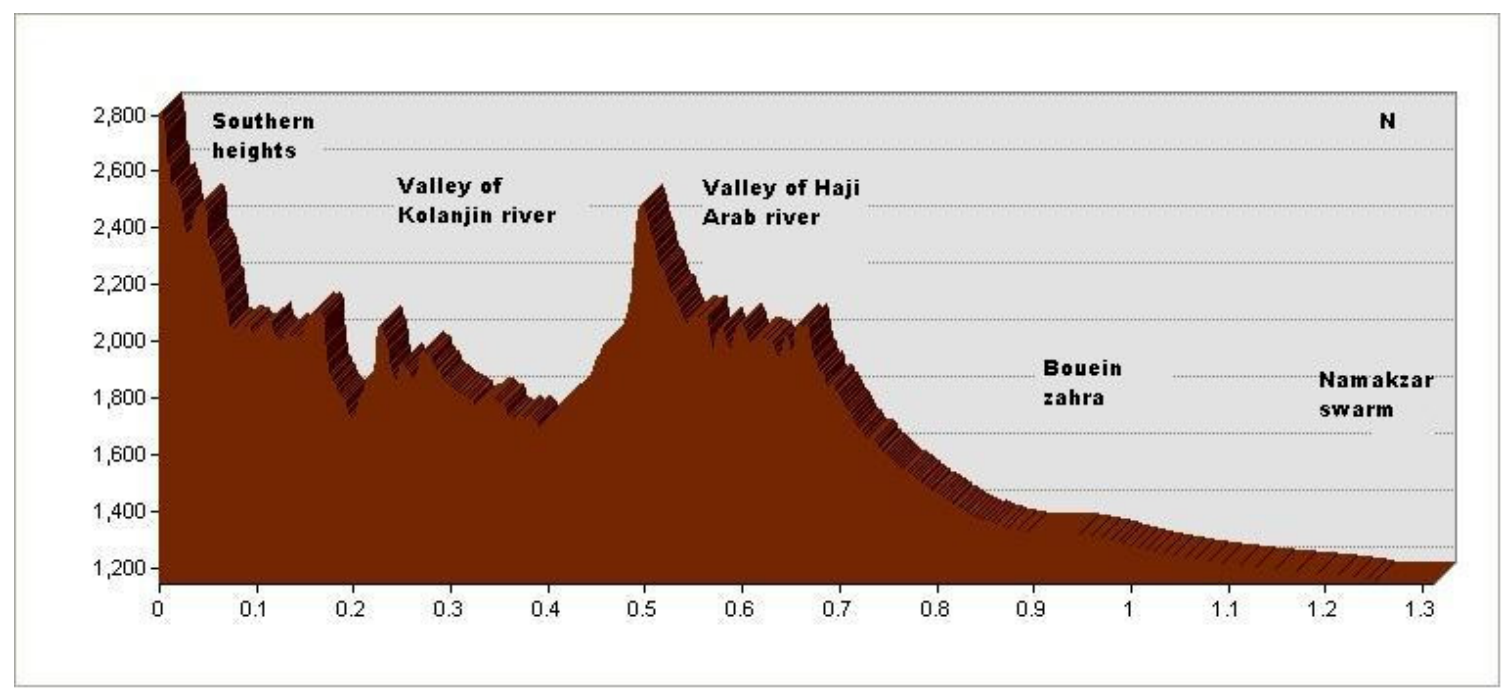

Figure 22. Southern heights to Namkzar Swarm profile 


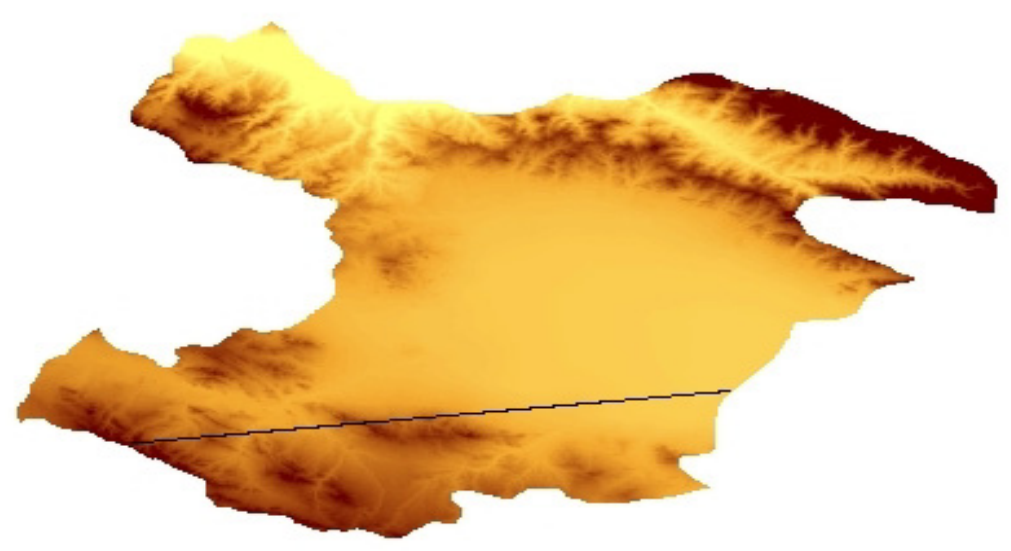

Figure 23. Southern heights to Namkzar Swarm profile

\section{Results}

Despite its small area, Qazvin province constitutes a variety of climatic conditions in it due to its different topographic structure that is with conspicuous fluctuations. Heights such as Alborz Mountain Range in Northern Qazvin Province, and its extension into the north east and north west, existence of two water sheds in the north of the province (Shahroud) and in the south (Shour River) explains this exotic climatologic diversity. Multivariate statistical methods have been used for the demonstration of the sub-climates of Qazvin Province and in this process, 9 main factors with the variance of more than $99.21 \%$ variance were specified for this purpose. Among the main factors the temperature-based, precipitation-based factors and humidity-based factors are more conspicuous in the central, eastern, northern and southern parts of the province. Then the values of the 9 main components underwent hierarchical cluster analysis using the ward method the result of which was the segregation of the province into 9 main sub-climates. This regionalization conforms to a great extent with the realities of the province, particularly with the configuration of the topography. Sub-climates in the northern half of the province which are of high diversity are more conspicuous from the central half in which the Qazvin plain is located. Macro-climately speaking, the climate of Qazvin Province is divided into the two mountainous and plain climates. The mountainous areas are divided into the mild and cold and the plain areas are divided into mild and relatively warm climates. The results of the clustering show that the northern mountainous areas comprising West and East Alamout and part of Alborz mountain range together with the Siyalan and Alamount peaks are the most humid parts of the province. The low areas around Manjil Dam Lake in the north-west part of the province have a quasi-Mediterranean climate. Figures 20 and 21 show the topographic profile between these two climates and evidence in favor of the climatic demarcation. In the southern parts of the province a few ranges of heights lie parallel to one another. These heights link with Kharghan and Dargazin in Hamedan province and enjoy a high-precipitationand cold climate. The eastern and central areas that cover Qazvin plain enjoy a semi-hot and low-participation climate. The topographical profile in figures 21 and 22 explain this climate change with the arrangement of the topography. The mountain skirt areas in the north Qazvin plain that link the mountainous areas to plain areas is an important agricultural hub and contributes to the economic development.

\section{References}

Alijani, B. (2002). Synoptic Climatology, Samt Publications, Tehran, Iran.

Alijani, B., \& Kaviani, M. (1992). Fundamentals of Climatology, Samt Publications, Tehran, Iran.

Ayoade, J. O. (1978). On the Use of Multivariate Techniques in the Climate Classification and Regionalization. Arch.Met.Geopen.Biokl.Ser.B, 2(1), 157-164.

Badraddin, Y., \& Mohammad, A. (1997). Climatic Classificationof Saudi Arabia: An Application of Factor Cluster Analysis. Geo-journal, 41(1), 69-84. http://dx.doi.org/10.1023/A:1006827322880

Carbajal, N. L., Pinda-Matinez, E., \& Medina, R. (2007). Regionalization and Classification of Bioclimatic Zones in the Central Northeastern Region of Mexico Using Principal Component Analysis (PCA). Journal of Universidad National Autonomic de Mexico, 20(2). 
Christos, J. L. (2009). Winter Cloudiness Variability in the Mediterranean Region and its Connection to Atmospheric Features. Theoretical and Applied Climatology, 96, 357-373. http://dx.doi.org/10.1007/s00704-008-0046-0

Domroes, M., Kaviani, M., \& Schacfer, D. (1998). An Analysis of Regional and Inter-Annual Precipitation Variability over Iran Using Multi Variant Statistical Methods. Theoretical and Applied Meteorology Journal, 61, 151-150.

Dronekamp, K. (1991). Quantitative Research in Geomorphology, Tehran University Press, Tehran, Iran.

Ehrendorfer, M. (1987). A Regionalization of Austria Precipitation Climate Using Principal Component Analysis, Journal of Climatology, 7, 71-89. http://dx.doi.org/10.1002/joc.3370070107

Farajzadeh, M. (2002). Climatology Techniques, Samt Publications, Tehran, Iran.

Gaitani, N., Santamouris, M., Mihalakakou, G., \& Patargias, M. (2000). Cluster Analysis in Energy Classification of School Building, 27 ${ }^{\text {th }}$ Conference Epic 2006 AIVC, Lyon, France.

Ghayour, H., \& Montazeri, M. (2004). Regionalization of the Isothermic Regimes of Iran Using Basic Components and Cluster Analysis, Geography and Development, 4.

Heise, B., Bobertz, B., \& Harff, J. (2010). Classification of the Pearl River Estuary via Principal Component Analysis and Regionalization. Journal of Coastal Research, 769-779. $\mathrm{http}: / / \mathrm{dx}$.doi.org/10.2112/JCOASTRES-D-09-00100.1

Inanlou, H. (2003). The Effect of Climatic Elements of Qazvin Province in the Thermal Comfort of the Rural Houses. Unpublished PhD Thesis, University of Tehran, Iran.

Khorshiddoost, A., \& Azadi, M. (2009). Identification of Synoptic Climatic Types in Tabriz Station Using the Cluster Analysis Model, Tabriz University Geography and Planning Publications, $24^{\text {th }}$ Year, $28^{\text {th }}$ ed.,

Littmann, T. (2000). An Empirical Classification of Weather Type in the Mediterranean Basin and Their Inter Relation With Rainfall. Theoretical Applied Climatology, 66, 61-70.

Manly, B. G. (1994). Introduction to Multivariate Statistical Methods, Translated by Mohammad Moghaddam, Seyed Abolghasem Mohammadi Shooti, and Mostafa Aghaei, Pishtaz Elm Publications, Tabriz, Iran.

Masoudian, A., \& Darandeh, M. (2003). Synoptic Analysis of the Pervasive and Durable Frost in Iran (2nd ed.), Geography and Development Publications, Tehran, Iran.

Masoudian, A., Ghaedi, S., \& Mohammadi, B. (2006). Iranian Humid Areas, Tabriz University's Faculty of Literature and Humanities. Vizhenameh Joghrafia.

Miao, H., \& Wang, B. G. (2009). China Climatic Regionalization for Highway. Beijing Gongye Daxue Xebio Journal of Technology, 35, 89-95.

Mohammadi, H. (2010). Applied Climatology, Tehran University Press, Tehran, Iran.

Montazeri, M. (2003). Application of Multivariate Statistical Methods in Regionalization of Climatic Areas: Isfahan Case Study. Geographical Research Qauarterly, 28(3).

Pourtaheri, M. (2003). Application of Multi-Attribute Decision Making methods in Geography, Tehran University Press, Tehran, Iran.

Sarraf, S., \& Rajaei, B. (1998). Application of Factor Analysis in the Study of Climate Elements, Tabriz University's Literature and Humanities Faculty's Press. Tabriz, Iran.

Shourmeij, R. (1972). The Study of Qazvin Province, Textbooks Compilation and Planning Department (1st ed.). Textbooks Printing and Publication Company, Tehran, Iran.

White, D., Richman, M., \& Yarnal, B. (1991). Climate Regionalization and Rotation of Principal Component. International Journal of Climatology, 11, 1-2. http://dx.doi.org/10.1002/joc.3370110102

White, F. J., \& Perry, A. H. (1989). Classification of the Climate of England and Wales Based on Agro Climatic Data. International Journal of Climatology, 9, 271-291. http://dx.doi.org/10.1002/joc.3370090305

Willmott, C. J. (1978). P-mode Principal Component Analysis, Grouping and Precipitation Regions in California Archive for Meteorology. Geophysics and Bioclimatology Series B, 26, 277-295.

Yunus, F. (2011). Delineation of Climate Divisions for Peninsular Malaysia, Geo Spatial World Form, Dimensions and Directions of Geo Spatial Industry, Hyderabad, India. 
Zare-Chahooki, M. (2010). Multivariate Research Methods in SPSS Software. Natural Resources Faculty of Tehran University, Tehran, Iran.

\section{Copyrights}

Copyright for this article is retained by the author(s), with first publication rights granted to the journal.

This is an open-access article distributed under the terms and conditions of the Creative Commons Attribution license (http://creativecommons.org/licenses/by/3.0/). 